\title{
ОСОБЛИВОСТІ ПРАВОВОГО РЕГУЛЮВАННЯ СПЛАТИ ЄДИНОГО СОЦІАЛЬНОГО ВНЕСКУ АДВОКАТОМ - САМОЗАЙНЯТОЮ ОСОБОЮ, ЯКИЙ ТИМЧАСОВО $€$ НАЙНЯТИМ ПРАЦІВНИКОМ
}

Корінна Н. М.

У статті здійснюється аналіз правового регулювання сплати єдиного соціального внеску та подачі звітності, адвокатом - самозайнятою особою, який не веде відповідну діяльність, не отримує від неї доходи, але їі не зупинив. Автором окреслено прогалини законодавства, проаналізована судова практика та надаються рекомендації для вдосконалення правового регулювання й усунення прогалин, що на сьогодні спричиняє неправомірне подвійне оподаткування вищезазначених осіб.

Ключові слова: єдиний соціальний внесок, адвокатська діяльність, адвокат, зупинення адвокатської діяльності.

В статье проводится анализ правового регулирования уплаты единого социального взноса и подачи отчетности адвокатом - самозанятым лицом, который не ведет coomветствующую деятельность, не получает от нее доходы, при этом не остановил ее. Автором обозначены пробелы законодательства, проанализирована судебная практика и даются рекомендации по совершенствованию правового регулирования и устранения пробелов, которые на сегодня вызывают неправомерное двойное налогообложение вышеуказанных лиц.

Ключевые слова: единый социальный взнос, адвокатская деятельность, адвокат, остановки адвокатской деятельности.

The legal regulation of the payment of single social contribution and the submission of reports by a lawyer - a self-employed person who doesn't carry out relevant activities, doesn't receive income from it, but hasn't stopped it, is analyzed in the article. The author outlines the gaps in the legislation, analyzes the jurisprudence and provides recommendations for improving the legal regulation and elimination of the gaps, which today leads to double taxation of the above mentioned persons.

The author concludes that in order to avoid the application of financial sanctions for non-payment of SSC and failure to report to lawyers - self-employed persons who don't temporarily perform their activities as self-employed persons, it is necessary to harmonize tax legislation (Tax Code of Ukraine, The Law of Ukraine "On Collection and Accounting of the Single Contribution to Compulsory State Social Insurance", The Order of the Ministry of Finance of Ukraine "On Approval of the Procedure for Formation and Submission by the Insurers of the Report on the Amounts of the Accrued Single Contribution to Compulsory State Social Insurance") with the law governing advocacy, it is the Law of Ukraine "On Advocacy".

This would allow not to cancel the obtained, according to the procedure established by law, the Certificate for the right to practice law today, as required by the procedure of "termination" of advocacy according to Art. 32 of the Law of Ukraine "On Advocacy" as the sole basis for the removal from the tax registration of a lawyer.

Корінна Н. М., 2019
For this, it is proposed to amend the tax legislation, namely, the articles governing the procedure for making changes in the payer's account, the procedure for removing him from the register, by fixing such a reason for the removal of a lawyer from the register of SSC as a "suspension" of advocacy, which would simplify the procedure of restoring the opportunity to practice law at such a desire and would not lead to the cancellation of the Certificate on the right to practice law.

Key words: single social contribution, advocacy, advocate, stopping advocacy.

Постановка проблеми та її актуальність. В Україні відбуваються кардинальні реформи в усіх сферах суспільного життя й адвокатська діяльність не стала винятком. Незважаючи на те, що законодавство, яке регулює адвокатську діяльність в Україні, почало формуватися 3 часів отримання Україною незалежності, дотепер воно проходить стадію становлення, має ще багато прогалин і колізій, які необхідно усунути для забезпечення захисту як прав самих адвокатів, так і врегулювання відносин «адвокат-клієнт», «адвокат-держава», «адвокат-адвокатське самоврядування», «адвокат-адвокат».

На сьогодні ще залишається багато болючих питань які не знайшли свого врегулювання. Ще у 2012 році з'явились нові форми здійснення адвокатом своєї професійної діяльності, а це зі свого боку викликало певну неузгодженість між різними нормативними актами, які врегульовують правовий статус адвоката залежно від обраної ним форми діяльності. Ще більше неузгодженості додало введення так званої «адвокатської монополії», яка вплинула на виникнення нових правовідносин, які вимагають і дотепер правового врегулювання. На сьогодні існує проблема та неоднозначне розуміння співвідношення статусів адвоката як самозайнятої особи, ФОП та найнятим працівником (юристом) при обрані системи оподаткування, обліку та при сплаті інших обов'язкових платежів. Через таку неузгодженість виникає необхідність звернення до податкових органів за роз'ясненнями законодавства, але як показала практика, консультації, які надають податкові органи щодо сплати податків, зборів та обов'язкових платежів, часто $є$ суперечливими і ставлять адвокатів в нерівне, невигідне становище стосовно інших платників податків. Підтвердження цьому $\epsilon$ вже сформована на сьогодні судова практика щодо таких справ, де суд у більшості випадків стає на бік адвокатів і вказує на незаконність та необґрунтованість прийнятого рішення органами Державної податкової служби [1]. Отже, неоднозначне трактування норм українського законодавства контролюючими органами, неузгодженість зако- 
нодавства тягне за собою порушення прав та інтересів адвокатів та спричиняє негативні наслідки, оскільки вони вимушені відстоювати свої інтереси в судах.

На сьогодні одне з найбільш обговорюваних й актуальних питань для адвокатів $\epsilon$ сплата такого обов'язкового платежу як - єдиного соціального внеску (далі $\epsilon$ С - H. К.) в разі, якщо адвокат фактично не здійснює адвокатську діяльність, не має доходу від неї, однак не зупинив їі, а працює як найнята особа.

Аналіз останніх досліджень і публікацій. Дана проблема на сьогодні активно обговорюється в адвокатських колах і досліджується науковцями. Так, висвітлення оподаткування різних форм адвокатської діяльності було здійснено в Методичних рекомендаціях з оподаткування адвокатської діяльності випущених Національною асоціацією адвокатів України авторами за загальною редакцією В. Гвоздія [2], висвітлено в поодиноких аналітичних статтях адвокатів-практиків: Н. Швець [3], К. Таламанчук [4], Д. Терземан [5], Канарьова Н. [6] і податківців, таких як Т. Федченко, Н. Фокіна та інших. Однак ґрунтовного наукового дослідження науковцями проблеми оподаткування адвокатської діяльності і сплати загальнообов' язкових платежів не проводилось.

Метою статті $\epsilon$ аналіз правового регулювання та правових наслідків для самозайнятої особи - адвоката, який стоїть на обліку в Національній асоціації адвокатів України, в Державній податковій службі України як самозайнята особа, але не здійснює адвокатську діяльність, не отримує доходу від неї, проте не зупиняє їі, та виробити пропозиції до законодавства для усунення існуючих колізій.

Виклад основного матеріалу. Іноді виникає ситуація, коли особа, яка отримала Свідоцтво про право на заняття адвокатською діяльністю, стала на облік в Єдиному реєстрі адвокатів України як самозайнята і стала на податковий облік, але при цьому не почала здійснювати адвокатську діяльність, не отримувала від такої діяльності доходи, а влаштувалася на непов'язану з адвокатською діяльністю роботу, при цьому не подала заяву до відповідної ради адвокатів про зупинення чи припинення адвокатської діяльності.

У цьому випадку виникає питання: чи буде така особа нести відповідальність за несплату єдиного соціального внеску (далі ЄСВ - Н. К.), як самозайнята особа та за неподання звітності щодо його сплати.

На сьогодні на це питання однозначної відповіді немає. Оскільки все залежить від того, наскільки особі вдасться довести свою позицію перед контролюючими органами, тому що законодавство не дає однозначної відповіді на це питання.

Позиція 1 - треба такій особі сплачувати $\epsilon C B$, подавати звіт про таку сплату, оскільки вона залишається на обліку, отже адвокат буде нести фінансову відповідальність за несплату ЄСВ та неподання звітності.

Так, у законодавстві визначено, що після отримання Свідоцтва на право заняття адвокатською діяльністю в порядку, визначеному розділом 2 Закону України «Про адвокатуру й адвокатську діяльність» № 5076-17 [7] в особи виникає обов'язок згідно зі ст. 65 Податкового кодексу України 9 (далі ПКУ - Н. К.): «стати на облік в територіальних органах Державної податкової служби України за місцем свого проживання протягом 10 календарних днів» [8].
Взяття на облік контролюючими органами самозайнятих осіб здійснюється незалежно від наявності обов' язку щодо сплати того або іншого податку та збору.

Відповідно до п. 13. Розділу II Про затвердження Порядку формування та подання страхувальниками звіту щодо сум нарахованого єдиного внеску на загальнообов'язкове державне соціальне страхування затвердженого Наказом Міністерства фінансів України 14.04.2015 р. № 435 в редакції від 01.08.2018 р.: «фізичні особи-підприємці, в тому числі ті, які обрали спрощену систему оподаткування, особи, які провадять незалежну професійну діяльність, члени фермерського господарства, зобов'язані подавати самі за себе Звіт незалежно від того, чи ведуть вони підприємницьку діяльність» [9], тобто з дефініції статті випливає те, що неважливо, веде особа діяльність чи ні, якщо особа $\epsilon$ на обліку, вона повинна подавати звіт.

Підставою для зняття 3 обліку в контролюючому органі самозайнятої особи $є$ процедура припинення незалежної професійної діяльності фізичної особи у відповідному уповноваженому органі (відповідно до п. 67.1 ст. 67 та пп. 65.10.4п., 65.10 ст. 65 Податкового кодексу України). [8] Та підстава, що особа не отримувала дохід від здійснення своєї незалежної професійної діяльності, не впливає на обов'язок щодо сплати ЄСВ. Так, відповідно до абз. 2 п. 2 ч. 1 ст. 7 Закону України «Про збір та облік єдиного внеску на загальнообов'язкове державне соціальне страхування» «у разі, якщо таким платником не отримано дохід (npuбуток) у звітному кварталі або окремому місяці звітного кварталу, такий платник зобов'язаний визначити базу нарахування, але не більше максимальної величини бази нарахування єдиного внеску, встановленої цим Законом. При цьому сума єдиного внеску не може бути меншою за розмір мінімального страхового внеску» [10].

Отже, виходячи з вище зазначених норм законодавства, можна зробити висновок: що незалежно від того, чи здійснює особа діяльність чи ні, чи отримує дохід чи ні, якщо вона зареєструвалася як самозайнята особа, перебуває на обліку в Єдиний реєстр адвокатів України (далі - ЄРАУ) та в податкових органах, вона зобов'язана сплачувати ЄСВ в розмірі мінімально встановленої суми в законодавстві та подавати звіти про таку сплату. До того ж на облік в ЄРАУ можна стати тільки після визначення своєї форми діяльності. І якщо особа має дійсне Свідоцтво на право на заняття адвокатською діяльністю (дія якого не зупинена або не припинена), а заява про знаття з обліку не подана, отже, права на здійснення адвокатської діяльності адвокат має в повному обсязі. Тому відслідкувати, чи користувався він наданими правами чи ні, неможливо. Саме тому адвокат зобов'язаний платити ЄСВ та подавати щорічний звіт про його сплату, інакше буде нести фінансову відповідальність у вигляді штрафу за несплату ЄСВ та не подання звіту.

Крім того, із цього приводу Голова ДФС України вже висловив свою думку. Так, у Листі ДФС України від 30.12.2016 р. №41658/7/99-99-13-02-01-17 було зазначено, що «обов'язки сплати ЄСВ особами, які провадять незалежну професійну діяльність (зокрема, адвокатами) продовжуються до державної реєстрації припинення такої діяльності та зняття їх із податкового обліку». Отже, адвокат зобов'язаний подати до податкового органу звіт із зазначенням типу форми «ліквіда- 
ційна» та відповідної заяви. Після проведення передбачених законодавством перевірок платників, звірення розрахунків та проведення остаточного розрахунку особу можуть зняти з податкового обліку. Без здійснення цієї процедури обов'язок по сплаті ЄСВ та подачі звітів не припиняється». Крім того, в індивідуальній податковій консультації від 26.10.2018 № 4589/Г/9999-13-02-03-14/ІПК, зазначається: «той факт, що особа є найнятим працівником і стоїть на обліку за основним місцем роботи і роботодавець вносить $\epsilon C B$ за неї і подає звітність, не позбавляє обов'язку звітувати особу як самозайнятої».

Цю позицію підтримали Житомирський апеляційний адміністративний суд у рішенні від 19 червня 2018 р., Дніпропетровський окружний адміністративний суд у рішенні від 29 листопада 2018 року у справі №0440/7200/18. До того ж у своєму рішенні від 11.09.2018 р. справа №1140/2244/18 Кіровоградський окружний адміністративний суд зазначив, що «незважаючи на наявність трудових відносин 3 роботодавцем, платник єдиного соціального внеску, визначений п. 5 ч. 1 ст. 4 Закону № 2464-VI, перебуваючи на обліку в контролюючому органі, зобов'язаний своєчасно та в повному обсязі нараховувати, обчислювати і сплачувати єдиний внесок відповідно до визначеної бази нарахування єдиного внеску. При цьому базу нарахування єдиного внеску зобов'язані визначати платники, як ті, що отримують, так і ті, які не отримують дохід від провадження незалежної діяльності».

Але проблема полягає в тому, що податковим законодавством не передбачена для зняття 3 податкового обліку така підстава, як «зупинення» адвокатської діяльності, що відповідає ст. 31 Закону України «Про адвокатуру та адвокатську діяльність» [7], що прямо порушує права особи, яка отримала Свідоцтво на заняття адвокатською діяльністю. Оскільки на сьогодні процедура зняття з податкового обліку самозайнятої особи прописана так, що особа вимушена за власною заявою «припиняти» дію Свідоцтва на право заняття адвокатською діяльністю і нести всі негативні наслідки, пов'язані з цим статусом (ст. 32 Закону України «Про адвокатуру та адвокатську діяльність») [7], оскільки це єдина підстава знятися з обліку і не платити ЄСВ і не подавати звітність. А отже, при бажанні відновити свою професійну адвокатську діяльність особа мусить заново здавати іспити, проходити стажування та всі інші процедури, передбачені Законом України «Про адвокатуру й адвокатську діяльність». Отже, виходячи з вищенаведених нормативно-правових актів, адвокат, який тимчасово не здійснює адвокатську діяльність (з будь-яких причин), мусить добровільно скасувати отримане Свідоцтво. На наш погляд, така ситуація вимагає узгодженості між двома нормативно-правовими актами: Законом України «Про адвокатуру і адвокатську діяльність» та Податковим кодексом України, до якого варто внести таку підставу для тимчасового знаття з обліку, як «зупинення» адвокатської діяльності, що носить тимчасовий характер і не вимагає скасування Свідоцтва на зайняття адвокатською діяльністю та має спрощену процедуру відновлення можливості провадити адвокатську практику.

Позиція 2. $\epsilon С B$ можна не сплачувати і звіт не подавати, фінансова відповідальність накладена не буде.

Так, відповідно до ст. 13 Закону України «Про адвокатуру та адвокатську діяльність», адвокат, який здійс- нює адвокатську діяльність індивідуально, є самозайнятою особою [7].

Підпункт 14.1.226 Податковий кодекс України визначає, що самозайнята особа - платник податку, який $\epsilon$ фізичною особою-підприємцем або провадить незалежну професійну діяльність за умови, що така особа не $\epsilon$ працівником у межах такої підприємницької чи незалежної професійної діяльності [8].

Незалежна професійна діяльність - діяльність лікарів, приватних нотаріусів, приватних виконавців, адвокатів, арбітражних керуючих <...> за умови, що така особа не $\epsilon$ працівником або фізичною особою-підприємцем та використовує найману працю не більш як чотирьох фізичних осіб.

Так, згідно абз. 3 ч. 4 ст. 5 Закону України 2464-VI «обов'язки платника ЄСВ виникають у самозайнятої особи з моменту початку провадження діяльноcmi», тобто необхідною умовою $€$ початок діяльності та докази підтвердження того, що діяльність здійснювалась особою. Отже, якщо особа не розпочала свою професійну діяльність, то й обов'язку щодо сплати ЄСВ не виникає [10].

Другою умовою виникнення обов' язку по сплаті $Є C B$ $\epsilon$ отримання доходу такою особою саме від незалежної професійної діяльності. Так, згідно п. 5 ч. 1 ст. 4 Закону України № 2464-VI, до платників єдиного соціального внеску відносяться «особи, які провадять незалежну професійну діяльність, а саме наукову, літературну, артистичну, художню, освітню або викладацьку, а також медичну, юридичну практику, в тому числі адвокатську, нотаріальну діяльність, або особи, які провадять релігійну (місіонерську) діяльність, іншу подібну діяльність та отримують дохід від цієї діяльності» [10].

Отже, необхідними умовами для сплати особою єдиного соціального внеску на загальнообов'язкове державне соціальне страхування $\epsilon$ провадження такою особою, зокрема, незалежної професійної адвокатської діяльності та отримання доходу від такої діяльності, а не наявність діючого Свідоцтва на право заняття адвокатською діяльністю. Так, Закон України 507617 у розділі 2 визначає процедуру набуття права на заняття адвокатською діяльністю. Отже, в разі дотримання іï, особа отримає право на заняття адвокатською діяльністю, підтвердженням чого буде видане Свідоцтво згідно зі ст. 12 вищевказаного Закону. Але Свідоцтво засвідчує саме право, а не обов'язок займатися адвокатською діяльністю. Тобто, Свідоцтво посвічує те, що особа має необхідні знання та навики для іï здійснення, але цим правом вона може і не скористатись. Крім того, згідно ч. 2 ст. 12 Закон України 5076-17, Свідоцтво про право на заняття адвокатською діяльністю не обмежуються віком особи та $є$ безстроковими, а отже не може бути анульоване внаслідок його невикористання.

Крім того, системний аналіз пп.14.1.226, 14.1 ПКУ та статей 4, № 2464-VI від 08.07.2010 свідчить на користь того, що особа, яка провадить незалежну професійну діяльність, зокрема адвокатську, вважається самозайнятою особою і платником єдиного соціального внеску на загальнообов'язкове державне соціальне страхування лише за умови, що така особа не $\epsilon$ найманим працівником у межах такої незалежної професійної діяльності і що вона отримує дохід саме від такої незалежної професійної діяльності. До того ж, якщо роботодавець здійснює сплату ЄСВ 


\section{Економічна безпека держави: теорія і практика}

та подає звіти за найманого працівника, то обов'язок таким платником вважається виконаний і платник вважається застрахованим [8].

До того ж при вирішенні податкових спорів застосовується судами принцип презумпції правомірності рішень платника податку п. 4.1.4, п. 4.1 ст.4 Податкового кодексу України, а саме «якщо норма закону чи іншого нормативно-правового акту, виданого на підставі закону, або якщо норми різних законів чи різних нормативно-правових актів припускають неоднозначне (множинне) трактування прав та обов'язків платників податків або контролюючих органів, то $\epsilon$ можливість прийняти рішення на користь як платника податків, так і контролюючого органу» [8].

Висновки. На сьогодні не врегульовано відносини щодо адміністрування ЄСВ при одночасному перебуванні фізичної особи у трудових відносинах та здійснення незалежної професійної діяльності, але судова практика поки що на боці платників податків. Цьому підтвердження $\epsilon$ рішення Житомирського апеляційного адміністративного суду № 817/505/18 від 19.06.2018 р. та Ухвала Верховного суду від 03.082018 р. на це рішення, Рішення Запорізького окружного адміністративного суду № 808/2072/18 від 16.07.2018 р [11].

Саме тому для запобігання в майбутньому порушень прав адвокатів - платників податків (самозайнятих осіб) необхідно врегулювати це питання законодавчо та спростити порядок зняття з обліку самозайнятих осіб-платників. Отже, для уникнення неправомірних фінансових санкцій до адвокатів - самозайнятих осіб, які бажають тимчасово зупинити свою діяльність, необхідно узгодити податкове законодавство з законодавством, що регулює адвокатську діяльність, і внести зміни саме до ст. 65 Податкового кодексу України, до Закону України 2464-17 [10], до п. 11.18 Наказу Міністерства фінансів України «Про затвердження Порядку обліку платників податків і зборів» від 09.12.2011 № 1588, до п. 1 розділу 5 Наказу Міністерства фінансів України «Про затвердження Порядку обліку платників єдиного внеску на загальнообов'язкове державне соціальне страхування та Положення про реєстр страхувальників» від 24.11.2014 р. № 1162, які регулюють порядок внесення змін в облікову справу платника шляхом закріплення в цих статтях, крім підстави «припинення» адвокатської діяльності, додатково таку підставу як «зупинення адвокатської діяльності», що передбачена в ст. 31 Закону України «Про адвокатуру та адвокатську діяльність» для зняття ії з обліку як застрахованої особи.

\section{Література}

1. Постанова Верховного Суду Касаційного адміністративного суду від 05.11.2018 р. справа № 820/1538/17 р. на постанову Харківського окружного адміністративного суду від 29.06.2017 URL: https://verdictum.ligazakon.net/ document/77661749.

2. Методичні рекомендації з оподаткування адвокатської діяльності / В. Гвоздій, І. Кальницька, Н. Матвійчук; Х. : Фактор, 2017. 32 с.

3. Швець Н. Адвокатська діяльність: облік, оподаткування, звітність. URL: http://www.visnuk.com.ua/ua/pubs/ id $/ 8109$.

4. Таламанчук К. «Не треба думати, як не заплатити $€ C B$, треба просто більше заробляти». URL: https://zib.com.ua/ua/135200-vgvozdiy_ne_treba_dumati_ yak_ne_zaplatiti_esv_treba_prosto_b.html

5. Терземан Д. ЄСВ, зміна організаційної форми діяльності адвоката та оптимізація оподаткування. URL: https://blog.liga.net/user/dterzeman/article/35290.

6. Канарьова Н. Адвокат як самозайнята особа та ФОП - як платити ЄCB? URL: https://news.dtkt.ua/simple/ individual-overall/54824.

7. Про адвокатуру і адвокатську діяльність: Закону України від 05.07.2012 р. № 5076-17 URL: https://zakon.rada.gov.ua/laws/show/5076-17.зі змінами.

8. Податковий кодекс України: Закону України від 02.12.2010 р. № 2755-VI зі змінами. URL: https://zakon.rada.gov.ua/laws/show/2755-VI.

9. Про затвердження Порядку формування та подання страхувальниками звіту щодо сум нарахованого єдиного внеску на загальнообов'язкове державне соціальне страхування: Наказ Міністерства фінансів України від 14.04.2015 № 435 ( редакції 01.08.2018 року). URL: https://zakon.rada.gov.ua/laws/show/z0460-15.

10. Про збір та облік єдиного внеску на загальнообов'язкове державне соціальне страхування: Закону України від 08.07.2010 р. № 2464-VI URL: https://zakon.rada.gov.ua/laws/show/2464-17.

11. Ухвала Верховного суду від 03.082018 р. на Рішення Запорізького окружного адміністративного суду № 808/2072/18 р. від 16.07.2018 р. URL:https://protocol.ua/ua/nayaktualnishi_rishennya_ sudiv_z_pitan_opodatkuvannya_advokatskoi_diyalnosti_u_ 2018_2019_rr/.

Корінна Н. М., аспірант кафедри фінансового права Навчально-наукового інституту права Університету державної фіскальної служби України, адвокат 